\title{
Dr. Butendieck, et al, reply
}

We read with great interest the response of Dr. Besse, et $a l^{1}$, to our letter, "Unusual presentation of giant cell arteritis in 2 patients: uterine involvement," published in The Journal of Rheumatology ${ }^{2}$. We are glad that the authors shared their experience in identifying systemic disease with the use of positron emission tomography/computed tomography after finding localized involvement on histopathology from adnexectomy. As additional cases are published, we hope that the recognition of gynecologic giant cell arteritis (GCA) and other more unusual presentations of GCA with systemic involvement will continue to increase.

RONALD ROLF BUTENDIECK JR., MD, Division of Rheumatology,

Department of Internal Medicine, Mayo Clinic; ANDY ABRIL, MD,

Division of Rheumatology, Department of Internal Medicine, Mayo

Clinic; CHERISE CORTESE, MD, Department of Pathology, Mayo Clinic,

Jacksonville, Florida, USA. Address correspondence to Dr. R.R.

Butendieck Jr., 4500 San Pablo Road, Jacksonville, Florida 32224, USA.

E-mail: Butendieck.ronald@mayo.edu

\section{REFERENCES}

1. Besse MC, Collercandy N, Diot E. Gynecologic vasculitis: positron emission tomography-computed tomography contribution in a rare localization of giant cell arteritis [letter]. J Rheumatol 2019;46:439.

2. Butendieck RR, Abril A, Cortese C. Unusual presentation of giant cell arteritis in 2 patients: uterine involvement [letter]. J Rheumatol 2018;45:1201-3.

J Rheumatol 2019;46:4; doi:10.3899/jrheum.181086 